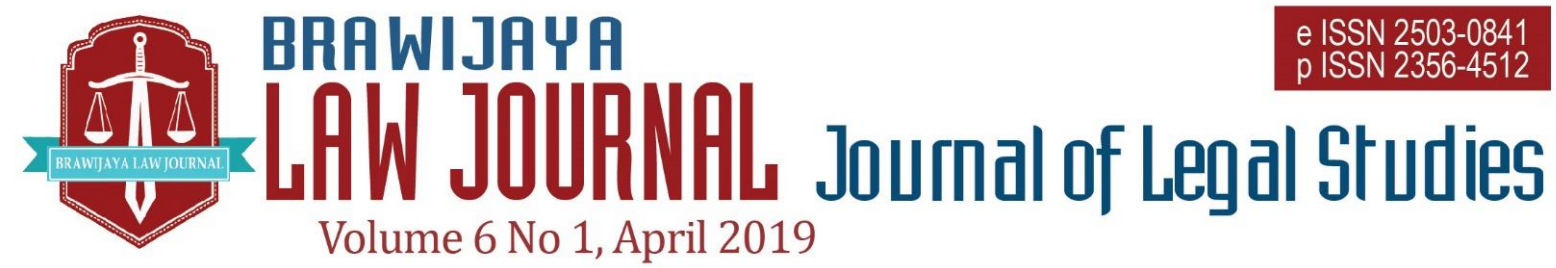

Nationally Accredited No. 30/E/KPT/2018 Dated 24th October 2018

This work is licensed under a Creative Commons Attribution-NonCommercial 4.0 International License

\title{
Development of Non-Litigation Civil Dispute Settlement Model Based on Madurese Local Wisdom to Reduce Cases Accumulation in Court
}

\author{
Uswatun Hasanah $^{a}$, Mohammad Amir Hamzah ${ }^{b,}$ Indien Winarwati ${ }^{c}$ \\ ${ }^{a}$ Faculty of Law, University of Trunojoyo Madura \\ Email: uswatun.hasanah@trunojoyo.ac.id \\ ${ }^{b}$ Faculty of Law, University of Trunojoyo Madura \\ Email:amhamz@gmail.com \\ ${ }^{c}$ Faculty of Law, University of Trunojoyo Madura \\ Email: indien_w@yahoo.com
}

Submitted : 2018-12-12 | Accepted : 2019-03-25

\begin{abstract}
Madurese community prefer to settle civil disputes outside the court by generating peace between the parties in the form of undertable bond, while the mediation results outside the court, the legality is weak. In this regard, this study would like to produce model of non-litigation civil dispute settlement that guarantees binding force of settlement so have binding strength as well as dispute settlement through mediators in court. This research is normative-qualitative research, so the method is combination of legal research methods and sociological research methods. The study results indicate that the mechanism to settle civil disputes in Madura is carried out peacefully through consensus meetings with the mediators help. The mediation has the binding power of customary law because it is based on the voluntary willingness of the parties, carried out through deliberation. This is in line with the local wisdom values such as the value of maintaining "shame" and the value of respect for parents, ulama (Keyae), and leader. Institutionalization of civil disputes settlement in Madurese community through conducted certification to mediator's village, legitimized by regional regulation, and accommodates the law in society because the law applies in accordance with the sense of justice of the community.
\end{abstract}

Keywords: civil disputes settlement; local wisdom of madurese community; mediation

\section{INTRODUCTION}

Cases accumulation is logical consequence of the many civil disputes submitted to the court because, judicially the Civil Procedure Code (HIR) itself does not limit when a civil dispute must be settled. ${ }^{1}$
1 The accumulation of cases in state courts, excessive work load of judges and law enforcers, and corruption of judicial bodies has proven the limited performance of the state in providing legal and justice services. See Sulistyawati Irianto, "Menuju Pembangunan Hukum Pro-Keadilan rakyat dan Perempuan" in Antonius Cahyadi and Dony Danardono (ed). Sosiologi Hukum dalam 
As result, to settle civil disputes through court need much time, effort, and costs. Therefore, dispute settlement through non-litigation procedure is an alternative to civil dispute settlement because, the basis of non-litigation dispute settlement is a win-win solution that prioritizes the justice principle for the parties. However, Law Number 30 of 1999 on Arbitration and Alternative Dispute Settlement did not set out clear about the process and outcome legality of mediation out of court. Though, it is not infrequently the peace results between the parties were carried out undertable bond.

As the Madurese community did in dealing with disputes, they prefer dispute settlement peacefully based on local wisdom that is settled through the village chief. However, when it comes to disputes that have to do with religion, they generally ask Keyae for advice. Hence, Keyae is mediator in settling disputes related to disputes that have to do with religion such as marriage, inheritance, grants, and so on. The figure of ghuru(Keyae) for the Madurese community is role model as well as reference for all matters relating to morality and religious aspects.

Given the importance of dispute settlement as the basis for legal certainty creation and justice, it needs regulations that empower the non-litigation civil disputes settlement based on local wisdom. The substance should contain matters related to non-litigation civil disputes settlement out of court. For this reason, the purpose of this study is to create the policy about nonlitigation civil dispute settlement model that guarantees the binding force of the non- litigation civil dispute settlement results because it fits the sense of justice of community so that it can reduce the accumulation of cases in court. With the model development through the institutionalization of local wisdom-based non-litigation dispute settlement that has binding power because, it is in accordance with the sense of community justice, accumulation of cases in court can be reduced as implementation of the principle of "just delayed is just denied".

\section{LEGAL MATERIALS AND METHODS}

This research is normative-qualitative research, so the design and method are combination of legal research methods and sociological research methods. The legal perspective appears in the legislation analyses in the field of settling non-litigation civil disputes, that is Law Number 30 Year $1999^{2}$, Law Number 6 of $2014^{3}$, and Law Number 12 of $2011^{4}$.

In sociological perspective, the analysis is directed at matters relating to the formation of non-litigation civil dispute settlement models. Data collection techniques were carried out through in-depth interviews with parties who had disputed and chose mediation outside the court, village chiefs and Keyae who had been mediators in settling non-litigation civil disputes in Madura (Bangkalan, Sampang, Pamekasan, Sumenep), conduct Focus Group Discussions on April - Nopember 2018. FGD is conducted by researchers with community leaders and government officials in order to discuss about the non-litigation
Perubahan (Jakarta: Yayasan Pustaka Obor Indonesia, 2009) p.7,8

2 Undang-undang Republik Indonesia Nomor 30 Tahun 1999 tentang Arbitrase dan Alternatif Penyelesaian Sengketa.
3 Undang- undang Republik Indonesia Nomor 6 Tahun 2014 tentang Desa.

4 Undang-Undang Republik Indonesia Nomor 12 Tahun 2011 tentang Pembentukan Peraturan Perundang-undangan. 
civil dispute settlement model based on madurese local wisdom to examine force of binding local-wisdom based mediation. Furthermore, the data obtained is analyzed to produce non-litigation civil dispute settlement model that has binding strength as dispute settlement through mediator in court.

\section{RESULT AND DISCUSSION}

\section{Mechanism for Settling Non-Litigation Civil Disputes in Madurese Communities}

For Madurese who still follow their customary law, dispute settlement using customary law is felt could fulfill the sense of justice. This is because, customary law in addition to reflecting the people mentality, customary law is also manifestation of community values that accommodate the community and individual interests, including the disputed parties. In the inheritance context that happened to the Madurese community, in general it was not carried out through the court but was settled by deliberation by the heirs ${ }^{5}$.

From various civil cases that have entered the district court over the past 5 (five) years (2012-2016) this shows that, inheritance cases are cases that are rarely submitted to court. Likewise, data on inheritance cases in religious courts show the lowest ranking compared to divorce and polygamy cases. Data from all Religious Court in Madura over the past 5 (five) years

\footnotetext{
Uswatun Hasanah and Et Al, 'Pluralisme Hukum Dalam Penyelesaian Sengketa Warisan Pada Masyarakat Madura' (2018) 11(1), Arena Hukum, 168

6 Primary data was compiled, 2018. Research findings of Fransz and Keebet von Benda Beckmann, that 80 percent of the decisions of district court judges in West Sumatra contained customary law, see Sulistyowati Irianto, Pluralisme Hukum di Indonesia dan Di Berbagai Negara Dalam Era Globalisasi (Jakarta : BPHN, 2007), 4,5
}

(2012-2016) concerning the number of cases, there are 3 inheritance cases from 7980 cases entered in Bangkalan Religious Court, there are 2 inheritance cases from 7223 cases entered in Sampang Religious Court, there were 7 inheritance cases from 8988 cases that were included in Pamekasan Religious Court, there were 8 inheritance cases out of 9369 cases that entered Sumenep Religious Court. ${ }^{6}$

The customary law is synonymous with traditional communities because empirically the customary law is community that still traditional. ${ }^{7}$ In humanity, there are many other legal reviews that more work harmonically rooted in the culture of law community that is attached to the law of religion, custom, and other social deal. ${ }^{8}$ This traditional nature has been recognized by the 1945 Constitution of the Republic of Indonesia, specifically Paragraph (2), which affirms that "the State recognizes and respects customary law units along with their traditional rights as long as they are alive and in accordance with community development and principles the Unitary State of the Republic of Indonesia, which is regulated in law ". 9

A village or legal alliance is headed by tribal chief or village chief (kepala desa). According to the customary law, the tribal chief is commissioned to maintain the life of law in their tribe or community, keeping the law to work properly. Moreover, if there is a dispute between residents, the

7 Dominikus Rato, 'Revitalisasi Peradilan Adat Pada Masyarakat Ngada Berbasis Kearifan Lokal' ( 2015) 92(May-August), Yustisia, 60

8 Franz von Benda-Beckmann, Changing Legal Pluralism in Indonesia, $\mathrm{VI}^{\text {th }}$ International Symposium Commission on Folk Law and Legal Pluralism, Ottawa (1990), 200

9 If it is not possible to refer to it as law because it does not fulfill the formal legal attributes in the perspective of a general flow, then let us name non-state law as hybrid law or unnamed law. See Franz von Benda-Beckmann, above n 5 
community could bring the dispute to the village chief.

Generally, the use of deliberation in settling disputes in the Madurese community involves third parties as mediators. The mediator function is important in the mediation process, for which the mediator must identify various causes of the occurrence of disputes and make an approach in order to overcome them. The mediation purpose are : (a) finding alternative solutions to settle the disputes that arise between the parties and it can be accepted by the dispute parties; (b) achieving a better communication between the dispute parties. ${ }^{10}$ Mediators as external parties or third parties are commissioned to assist the parties in settling disputes so that an agreement can be reached and can be accepted by both parties to settle the dispute. ${ }^{11}$

Appointment of third party as mediator can occur because of : (a) his own will (nominating himself); (b) appointed by other parties (for example tribe chief); (c) requested by both parties ${ }^{12}$. In the Madurese community, the appointment of the third party as a mediator could be because he/she is appointed by the party, or because he/she is requested by both parties. As in the settlement of inheritance disputes, the mediator is a society figure, the village chief. ${ }^{13}$ The appointment of village chief or society figure because, they are requested by

10 Valerine JL Kriekhoff, 'Mediasi : Tinjauan Dari Segi Antropologi Hukum' in TO Ihromi (ed), Antropologi Hukum Sebagai Bunga Rampai (Jakarta : Obor Indonesia Foundation,1993) 223

11 Chandra Dewi Puspitasari, Alternatif Penyelesaian Sengketa Asuransi Melalui Badan Mediasi Asuransi Indonesia (BMAI)' (2007) 4(2), Journal Civics 95

12 Valerine JL Kriekhoff, above n 5

13 Village chief who are also religious leaders have received better respect by the Madura community. In Madura, religion is an organizing principle for both parties, or because they are appointed by another party.

In addition, there are 3 mediators according the typology by Moore. That are social mediators, authoritative mediators, and independent mediators. First, social mediators play role in dispute on the basis of social relations existence between mediator and parties in the dispute. The mediator in this typology, are part of existing or ongoing social relationship. Authoritative mediators try to help the disputing parties to settle differences between them and have strong or influential positions so that they have the potential or capacity to influence the final outcome of the mediation process. ${ }^{14}$ The rationale for the communities to prefer social mediators because the mediator is regarded as a party capable of maintaining the secrets of disputes that occurred between the parties. ${ }^{15}$ In Addition, the uniqueness of mediation dispute resolution in Madurese society is the settlement based on the values of local wisdom, namely respect for parents, ulama, and formal leaders ${ }^{16}$.

In settling inheritance disputes, they will ask help from elder relatives first ${ }^{17}$. In this case, it means that the mediator is selected typology of parties in the dispute. However, if the elder's relatives do not succeed, the disputing parties come to the village chief to ask for their dispute to be settled. In general, the Village chief (Klebun) will not settle the inheritance dispute, but will

Madurese, see Kuntowijoyo, Radikalisasi Petani (Yogyakarta: Bentang Intervisi Utama, 1994) 87

14 Titik Fatimah and Hengki Andora, 'Pola Penyelesaian Sengketa Tanah Ulayat Di Sumatera Barat' (2015) 4 (1) Jurnal Ilmu Hukum 47

15 Uswatun Hasanah Et Al, above n 2, 177

16 Uswatun Hasanah, Et Al, 'Penyelesaian Sengketa Tanah Waris Berbasis Kearifan Lokal Masyarakat Madura ' (2017) Proceedings of UMM 1066

17 Results of an interview with Sukarman, Petapan Village, Labang Sub-District, Bangkalan Regency, July $5^{\text {th }}, 2018$ 
ask for help from ulama (Keyae) to become mediators in settling the inheritance dispute. This is in line with the results of Yulianti's study that Madurese people put village officials as figures who can be used as mediators when they dispute. ${ }^{18}$ However, if the dispute faced concerns religious issues such as the distribution of inheritance, the figures involved in settling the dispute are religious leaders.

\section{Motives Madurese for Selection of Non- Litigation Civil Dispute Settlement}

Practice of property inheritance division, generally divided into two kinds done in peace by heirs, be settled through the courts. For the Madurese community, the inheritance distribution is always done peacefully between the parties. This is reflection that most Indonesians have tendency to settle disputes in peaceful manner. Because basically the culture for conciliation or deliberation is widespread community value in Indonesia. ${ }^{19}$ This method is recognized as effective in settling disputes or disputes while being able to eliminate feelings of revenge. ${ }^{20}$ Thus, it is understood that the Madurese prefer customary law that use the consultation principle in inheritance dispute settlement in order to maintain harmony, maintaining relationships and kinship relation between the parties. ${ }^{21}$. This is in accordance with the general mentality of indigenous people who

18 Rina Yulianti and Sri Maharani, 'Penyelesaian Sengketa Informal Berbasis Komunitas Adat Terpencil di Kepulauan Kangean (Pilihan Hukum dan Posisi Dalam Sistem Hukum Negara)' (2012) 12 (2) Jurnal Dinamika Hukum 199

19 Arfan Faiz Muhlizi, 'Bantuan Hukum Melalui Mekanisme Nonlitigasi Sebagai Saluran Penguatan Peradilan Informal Bagi Masyarakat Adat' (2013) 2(1) Jurnal Rechtsvinding 71

20 Ahmadi Hasan, 'Penyelesaian Sengketa Melalui Upaya (Non Litigasi) Menurut Peraturan Perundang-Undangan' (2007) 5 (January - June) Jurnal AL-BANJARI 2,3 have communal characteristics, namely prioritizing common interests rather than their interests.

On the other hand, the lack of understanding of court procedures in the court as well as transportation to distant court locations is technical obstacle for the community to access justice through state law. Therefore, the lack of understanding of procedural legal procedures in court has implications for the need to be accompanied by lawyer. The implication is that sense of justice is not necessarily achieved yet but expensive fees must definitely be spent, because of paying attorney's fees and transportation costs to the court ${ }^{22}$. Based on that, the community uses dispute settlement based on customary law which prioritizes deliberation and peace so that they can maintain harmony, kinship relationship, and can maintain friendship between the parties.

\section{Binding Force of Inheritance Dispute Settlement Mediation in Madurese \\ Community}

Based on the interview results with Rasyid that the mediation results were written in written form signed or witnessed by the village chief, the essence was manifestation of the inheritance dispute settlement by the parties ${ }^{23}$. According to Cindawati ${ }^{24}$, volunteerism is constitutive element of the binding power of the mediation results, because the presence of

21 Results of an interview with Zainul, Kemoning Village, Tragah Sub-District, Bangkalan Regency, July $23^{\text {th }}, 2018$

22 Results of an interview with Jazuli,Sogian Village, Ambunten Sub-District, Sumenep Regency, August $25^{\text {th }}, 2018$

23 Results of an interview with Rasyid as the Head of Pasongsongan Village, Sumenep Regency, July $28^{\text {th }}, 2018$

24 Cindawati, 'Analisis Kekuatan Mengikat Kontrak Sebagai Dasar Yuridis Dalam Bisnis Internasional' (2016) 9 (3) Arena Hukum 386 
unauthorized third party interfering in the mediation contents shows that the mediation results are no different from agreement. What has been agreed upon by the parties will lead to the binding power for agreement as law. What someone states in legal relationship becomes law for them. This is not only moral obligation but also legal obligation that the implementation must be obeyed. ${ }^{25}$

Dispute settlement through mediation outside the court, pursuant to Article 6 paragraph (1) of the Law Number 30 of 1999 that civil dispute or difference of opinion can be settled by the parties through alternative dispute settlement that is based on good faith to the exclusion of settlement of litigation in the District Court. Furthermore, the written dispute settlement or difference of opinion agreement is final and binding on the parties to be carried out in good faith and to be registered in the Court of Justice in maximum period of 30 (thirty) days from the signing (Article 6 paragraph (7) of Law Number 30 of 1999. By looking at these provisions, the dispute settlement agreement outside the court must be written and must be registered with the District Court.

The problem is, these provisions were never implemented by the Madurese community related to the registration obligation to state court on the results of written agreement as the mediation results in village, because Madurese community have habit that they did not want complicated or convoluted matter, they want very practical and fast, moreover, distance and ignorance of court procedures to cause them reluctant to court so they prefer enough mediation dispute settlement in village-level with the written agreement results known by the village chief. $^{26}$

Speaking of binding power of legal conditions, the essence is not solely based on compelling forces, in particular in customary law communities, binding power is more driven by reasons of decency or trust.${ }^{27}$ As is the case, the binding power of mediation as a dispute settlement in the Madurese communitydriven more by reasons of decency or trust. This is related to the mentality of religio-magical indigenous people, who consider that nature consists of parts of each other as one entity, which considers that there is close relationship between humans and their environment so that equilibrium must be maintained through the principle of restitutio in integrum so that peace in the village is maintained ${ }^{28}$. Klebun (village chief) is village figure who is given the trust by indigenous people to maintain peace in the village. Based on interviews with Efendi, obtained

information that in each there is problem in the village, klebun (village chief) is central to the position because klebun are expected to have ability to settle and according to the provisions, Klebun must settle every problem in their village, because the authority lies in its ability to solve village problems including settling disputes among the village residents ${ }^{29}$.

Mediation is a means of settling disputes that is in accordance with the

28 Uswatun Hasanah and Et Al, above n 2, 176

29 Results of an interview with Efendi, Poreh Village, Lenteng Sub-District, Sumenep Regency, August $30^{\text {th }}, 2018$

26 Uswatun Hasanah and Et Al.,above n 2, 180

27 Theresia Ngutra,' Hukum dan Sumber-sumber Hukum' (2016) 11(2) Jurnal Supremasi 209

120 | Hasanah, Hamzah, Winarwati - Development of Non-Litigation Civil Dispute Settlement Model... 
mentality of the Madurese community, so that mediation has binding force in traditional manner. The binding force of mediation as a dispute settlement among Madurese is due to the following: First, the mediation occurrence was due to the voluntary willingness of the parties to settle the dispute through mediation. Based on the interviews results with Muhammad, that the party whose rights were disrupted usually came to the Village chief to ask for their rights to be restored 30 . Second, through mediation is relations balance between community members, one with other community members can be maintained. The Madurese community which is still communal, prioritizes social harmony in every movement, especially related to dispute settlement, if there is dispute it will be settled peacefully, mediated by klebun (village chief) as central figure in Madura custom to maintain peace. ${ }^{31}$ This is in line with the opinion of Abbas that the communal as nature of community emphasizes that individuals who are in dispute must try to create social harmony and eliminate disputes $^{32}$. If he does not try and is not willing to settle the dispute through the mediation path, then the individual gets negative assessment of community; Third, mediation in the Madurese community has binding force because of the existence of local wisdom values that have become the culture of the Madurese community. Values such as to maintain "todus" (shame or

30 Results of an interview with Muhammad, Binoh Village, Burneh Sub-District, Bangkalan Regency. August $14^{\text {th }}, 2018$

31 Uswatun Hasanah and Et Al, above n 2, 176

32 Syarizal Abbas, Mediasi Dalam Perspektif Hukum Syariah, Hukum Adat, dan Hukum Nasional, (Jakarta : Kencana Prenada Media Group, 2009), p. 273, 275 humiliated) and the value of respect for bhuppa bhabhu ghuru rato (father, mother, keyae, leader) has become guideline for all actions of Madurese community so that what has become agreement in mediation has binding force for the parties. Mediation as means of settling disputes, in harmony with the culture of Madurese who maintain "todus" (shame) because bringing dispute to court is embarrassing, especially marital disputes and inheritance disputes. This is in line with the results of Kaban's research on the Karo Community which stated that it was a very shameful thing for the Karo people if the issue of inheritance was brought to court ${ }^{33}$. In addition, as the implementation of safeguard "todus" namely their feelings to make their dispute hidden from the general public became basic consideration for Madurese to use mediation. Therefore, the mediation process is generally carried out at the home of one of their relatives, or although the mediation was conducted in community figure, it is solely because of community figure was considered as able to keep the secret of the dispute that occurred between the parties. ${ }^{34}$

Based on the interviews results with Hidayat that they were mediating because they would not be known by others, because it was disgrace to have dispute known to many people, especially about inheritance disputes. ${ }^{35}$ This is in line with the cultural values of the Madurese who abstain from

33 Maria Kaban, 'Penyelesaian Sengketa Waris Tanah Adat Pada Masyarakat Adat Karo' (2016) 28 (3) Mimbar Hukum 461

34 Results of an interview with Ibnu Hajar, Sumedangan Village, Pademawu Sub-District, Pamekasan Regency, July 12 $2^{\text {th }}, 2018$

35 Results of an interview with Hidayat, Batukerbuy Village, Pasean Sub-District, Pamekasan Regency, July $8^{\text {th }}, 2018$ 
being humiliated or have to endure todus (shame), especially those concerning the dignity and good name of the family. In this connection, mediation is the right choice to settle disputes that others will not know. The research result Hasanah, Et $\mathrm{Al}^{36}$ indicates that the value of respect for bhuppa 'bhabhu' especially at the whim of parents who have died, then the dispute that occurred on land inheritance and other parties can ultimately be settled through mediation and obtained the agreement of the magnitude compensation, even though logically economically, the compensation received by the heirs is not proportional to the market price of the land that is the dispute object, but it is carried out by the heirs in order to respect the oral testament of his parents (who wish to benefit from the use of land for educational purposes).

The mediator in mediating the inheritance disputes settlement among Madurese people, there are traditional leaders such as village leaders and religious leaders. Based on the discussion results in the Focus Group Discussion with community leaders in Sumenep Regency, information was obtained that in the majority of villages in Sumenep regency, the village chief was central in settling disputes in the village because the community always entrusted the settlement of the dispute to the village chief ${ }^{37}$, generally people in rural areas when facing dispute will ask for assistance from Klebun (Village chief) to mediate over the dispute they face. This is form of respect for rato (formal leader). ${ }^{38}$ So, the Madurese, when faced with inheritance dispute, the community will first have recourse to Klebun (Village chief) as form of homage to Rato figure, the next head of the village will be asked for help from religious leaders or Keyae as homage form to the ghuru figure to arbitrate on the inheritance dispute. Thus, it is clear that the value of bhuppa'bhabhu 'ghuru rato has become guide for the Madurese community including in settling disputes faced.

Thus, mediation in settling Madurese dispute has customary binding force because mediation is based on the voluntary willingness of the parties to settle their disputes, and the dispute settlement through mediation is means of settling disputes that is in line with the communal mentality of Madurese people and values of local wisdom such as the value of maintaining "todus" (shame) and the value of respect for bhuppa bhabhu ghuru rato so that the agreement resulting from the mediation of Madura community dispute settlement binds parties who have agreed to the mediation results.

\section{Institutionalization of Dispute Settlement Mediation of Madurese Community Through the Legal System}

To increase the binding force of inheritance dispute settlement results in mediation on madura communities can be done through 3 (three) forms through conducted certification to mediators village, legitimized by regional regulations, and hence the sense of justice ${ }^{39}$.

\footnotetext{
36 Uswatun Hasanah, above n 13, 1067

37 Results of Focus Group Discussion with Community Leaders (village chiefs and religious leaders) in Sumenep Regency, July 29th, 2018

38 Uswatun Hasanah, above n 13, 1068
}

39 According to Lawrence M. Friedman, there are three main elements of the legal system, namely: (1) legal structure (2) legal substance (3) legal culture. See Lawrence M. Friedman, The Legal System: A Social Science Perspective (New York :Russell Sage Foundation, 1975) 
1) Conducted

certification

to

\section{Mediators Village}

Legal structure involving various institutions created by the legal system with its various functions in order to support the system operation. One of them was the Court. ${ }^{40}$ The mediation data at trials that were successful nationally <4. ${ }^{41}$ Therefore, the mediation of the Madurese community disputes settlement needs to be structured so that mediation in the village can support legal dispute settlement system outside the court.

In mediating the dispute settlement of Madurese community, the mediator role was the Village chief (Klebun) and the Keyae. Structurally, pursuant to Article 26 of Law Number 6 of 2014 (Village Act), the village chief has task to implement village administration,

village development, village community and empowering coaching village community. In implementing the task as referred to in paragraph (1), the head of the village community is obliged to settle disputes in the village and fostering and preserving the socio-cultural values of the village community (Article 26 paragraph (4) of the Village Act).

Based on the interview results with Anwar that the village community hoped that the agreement reached through mediation held in the village should be able to provide basis for the court that the community agreed that there was no need to have trial because mediation was based on the parties wishes and the procedure had also been carried out in accordance with the mediation principles $^{42}$.

\footnotetext{
40 Sukresna, 'Pemberdayaan Lembaga Mediasi Dalam Penyelesaian Sengketa Di Bidang Pertanahan' (2012) 41 (1) MMH 84

41 Gatot Dwi Endro Wibowo, 'Aspek Hukum dan Kelembagaan Dalam Peningkatan Efisiensi dan
}

Regarding mediation, Supreme Court Regulation (PERMA) Number 1 of 2016 on Regulation of Mediation which is integrated into litigation procedures in court. In Article 1 PERMA Number 1 of 2016 it is stated that mediation is a way of settling disputes through the negotiation process to obtain agreement between the parties assisted by the Mediator. The mediator is required to have Mediator Certificate obtained after taking and is declared to have passed the Certified Mediator Training held by the Supreme Court or institution that has obtained accreditation from the Supreme Court (Article 13). Based on the provisions of PERMA Number 1 of 2016, that in order to become mediator, person must have Mediator Certificate, namely document issued by the Supreme Court or institution that has obtained accreditation from the Supreme Court stating that someone has attended and passed Mediation certification training. So, PERMA Number 1 of 2016 only regulates mediators who help parties in the negotiation process to find various possibilities for dispute settlement as litigation procedures in court, while mediation outside the court, in Article 36 paragraph (1) PERMA Number 1 of 2016 is stated that peace agreement with out-of-court dispute settlement can be submitted to the competent court to obtain Peace deed by filing lawsuit. The problem is that the Madurese culture who do not want to be convoluted, lack of understanding of the procedure in court proceedings, and the distance between the village and the court are the factors that reluctantly relates to the Madurese community dealing with the court.

\footnotetext{
Efektivitas Pengelolaan Wilayah Pesisir' (2009) 16 (1) Jurnal Hukum 1

42 Results of an interview with Anwar, Pasongsongan Village, Pasongsongan Sub-District, Sumenep Regency. August 8 ${ }^{\text {th }}, 2018$
} 
Based on the PERMA Number 1 of 2016 determines that the mediators who carry out the mediation functions in courts shall have mediator certificate then using the principle of analogy, the provisions of PERMA Number 1 of 2016, may be applied toward the village mediators or obligation to have Mediator Certification. Mediator certification is education and training to mediators up to certificate issuance by using the curriculum, time, and certain way organized by the Mediator Certification Agency in order to provide the knowledge, attitudes and behavior skill of Mediator. The procedure that must be done to receive mediator certification is to take mediator course for 40 hours and pass the theory test and practice exam (Decree of the Supreme Court Chief of the Republic of Indonesia Number 117 / KMA / SK / VI of 2018).

During this time, the mediator in the disputes settlement through mediation in the village over religious disputes was the village chief and Keyae. For this reason, village chiefs and employees can be certified as village mediators. The training budget for the certified mediators can be charged to the village budget is the governance budget, because one of duties of the village administration is settling disputes in the village (Article 26, paragraph (4) of the Village Act). In this case, the mediator role is important in helping smooth the mediation in order to settle the disputes faced by the village community.

\section{2) Increased Binding Force In Form Regional Regulation}

Legal substance is the rules, norms, and behavior patterns of human being in the system. So the legal substance concerns the applicable laws and regulations that have binding force and become guidelines for law enforcers. In other words, the substance also means products produced by people who are in a legal system that includes decisions issued, or new rules that are compiled. So, the legal substance includes everything that is the output of legal system in the form of regulations, decisions as far as all of these are used in the process concerned. ${ }^{43}$

Since the civil dispute settlement institutions, especially religious dispute (disputes in marriage and inheritance) in community Madura through this mediation has expanded and is applicable in almost all the regency in Madura, then substantially the necessary arrangements in this regard the legal figure as legitimate mediation of dispute settlement of Madurese community is not enough if only through the Village Regulation (PERDES), but it needs to be done through Regional Regulations (PERDA) so that its reach can cover the regency area.

Article 18 Paragraph (6) The 1945 Constitution of the Republic of Indonesia (UUD NRI) reads "Every Regional Government has the authority to stipulate Regional Regulations". The existence of this article indicates that the 1945 Constitution of the Republic of Indonesia has provided constitutional legitimacy to the Regional Government to form Regional Regulations. Furthermore, regional authority to establish Regional Regulations has been regulated in Law Number 12 of 2011 on Establishment of Legislation and Law Number 23 of 2014 on Regional Government.

Article 14 of Law Number 12 of 2011 regulates that Provincial Regulations and Regency/City Regulations contain

43 Sukresna, above n 32, 84

124 | Hasanah, Hamzah, Winarwati - Development of Non-Litigation Civil Dispute Settlement Model... 
material in the framework of implementing regional autonomy and tasks coadministration and accommodating regional special conditions and / or further elaboration of higher legislation. Similar provisions are also contained in Article 235 of Law Number 23 of 2014 which determines that to organize Regional Autonomy and Tasks Assistance, Regions form Regional Regulation (PERDA) (paragraph 1). PERDA as referred to in paragraph (1) contains content material: (a) implementation of Regional Autonomy and Assistance Tasks; and (b) further elaboration of the provisions of higher laws and regulations. In addition to the content material as referred to in paragraph (3), the Regional Regulation (PERDA) can contain local content material in accordance with the provisions of the legislation (paragraph 4).

The establishment of good local regulation must pay attention to the principles of the formation of legislation, as stated in Article 5 of Law Number12 of 2011, namely: (a) clarity of purpose; (b) appropriate forming institutions or officials; (c) compatibility between type, hierarchy and content material; (d) can be implemented; (e) utility and usefulness; (f) clarity of formulation; (f) openness.

Regarding the content material that can be regulated by the Regional Regulation (PERDA), Article 14 of Law Number 12 of 2011 determines that the following matters must be considered, namely: (a) PERDA may not conflict with higher laws and regulations, because one the content of the Regional Regulation (PERDA) is to further elaborate the higher legislation; (b) and the Regional Regulations (PERDA) can regulate

44 Iwan Sulistiyo, Et Al, 'Implementasi Asas Keterbukaan Dalam Proses Pembentukan Peraturan Daerah Dalam Rangka Otonomi Daerah Di Kabupaten Kendal (2018) 1(1) Jurnal Daulat Hukum 197 content material that aims to accommodate regional specific conditions. ${ }^{44}$ So, the material contained in the PERDA can come from several sides, including: (a) originating from delegation of laws; (b) because of regional initiatives; (c) elaboration of custom; (d) the translation of religion. Thus, the existence of a PERDA is expected to give meaning to the community, especially in accommodating local wisdom. ${ }^{45}$

Therefore, for the peace agreement resulting from mediation with village mediators to have binding and final power, the legal umbrella that provides legal basis and can guarantee legal certainty is very necessary. The existence of a legal umbrella is needed in order to improve the legality and legitimacy of written peace agreement resulting from the mediation as dispute settlement of Madurese community through village mediators, so that they do not only have customary binding force but also have final and binding force according to the national law.

\section{3) To Accommodate The Customary Law of the Madurese Community}

Legal culture is atmosphere of social thought and social forces that determine how the law is used. Legal culture is closely related to public legal awareness, the higher the legal awareness of the community, the better the legal culture will be created, in other words, the level of community satisfaction with the law is one indicator of the legal function. Legal culture by Friedman is referred to as attitudes and values that have a relationship with law and the legal system. ${ }^{46}$

45 Muhammad Suharjono, 'Pembentukan Peraturan Daerah yang Responsif Dalam Mendukung Otonomi Daerah' (2014) 10(February) Jurnal Ilmu Hukum 26

46 Sukresna, above n 32, 84 
Even though Law Number 30 of 1999 Article 6 paragraph (1) has stipulated that disputes or differences in civil opinion can be settled by the parties through alternative dispute settlement based on good faith overriding litigation settlement in the District Court. Furthermore, written dispute settlement or difference of opinion agreement is final and binding on the parties to be carried out in good faith and must be registered with the District Court within a maximum of 30 (thirty) days from the signing (Article 6 paragraph (7) Law Number 30 of 1999. By looking at these provisions, the agreement to settle disputes outside the court must be written and must be registered with the District Court. However, because of the peace agreement the results of mediation settlement religious dispute Madurese never registered at the Court with considerations as noted previously (not like convoluted, long distances between villages court) then need legislation that can be became the umbrella legislation on dispute settlement of Madurese with klebun and keyae mediators. Under these provisions, the institutionalization of dispute settlement of Madura community through legislation, will able to increase effectiveness because mediation has become habit of Madurese is out of court mediation, mediation through the villages mediator, the Village chief and / or Keyae. The regulation is in accordance with the conditions of special needs of Madurese community and there is no opportunity for other parties to take actions that can cause disruption or uncertainty over the agreements that have been reached through village mediators. Consequently, community legal awareness also will increase because the law is in accordance with the sense of justice of the community and ultimately can reduce the accumulation of cases in court.

\section{CONCLUSION AND SUGGESTION}

The mechanism for non-litigation civil disputes settlement in Madurese communities is carried out peacefully through consensus agreements with the help of mediators. The mediator is the village chief, he/ she help to settle the dispute. If the Village chief is unable to settle the dispute that submitted to him, especially the religious dispute, the Village chief (Klebun) will ask the ulama (Keyae) to become mediator in dispute settlement.

The reason Madurese prefer the nonlitigation civil dispute settlement model are to maintain harmony, kinship, and friendship between them. All of that is based on the value of respect to "bhuppa 'bhabhu' ghuru rato". In addition, the distance to go to the court, lack of the court procedures understanding and the high costs (both because the distance to the court is far from their home and the cost of lawyer is expensive, if you have to choose civil dispute settlement in the court) are the factor that make Madurese people prefer use nonlitigation civil disputes settlement.

Moreover, mediation of Madurese dispute settlement has binding power in the society because, the mediation is based on the voluntary willingness of the parties to settle their disputes, and deliberation through mediation. It is means, settling disputes that is in line with the communal mentality of Madurese, wisdom values local values such as maintaining "todus" (shame or humiliated) and the value of respect for "bhuppa bhabhu ghuru rato". Consequently, the agreement that is resulted from the mediation of Madurese dispute settlement binds parties who have agreed to the mediation results. In the end, the institutionalization of Madurese civil disputes settlement through three (3) elements of legal system that are the legal 
structure (conducted certification of mediator's village), legal substance (legitimacy through regional regulation), and the legal culture (of public awareness) is getting stronger for the use of mediation in village because it fits the sense of justice of the community.

\section{REFERENCES}

\section{Books}

Abbas, Syarizal, Mediasi Dalam Perspektif Hukum Syariah, Hukum Adat, dan Hukum Nasional (Jakarta: Kencana Prenada Media Group, 2009).

Benda-Beckmann, Franz von, Changing Legal Pluralisme In Indonesia, VI th Internatonal Symposium Commission on Folk Law and Legal Pluralisme, Ottawa (1990).

Friedman, Lawrence M, The Legal System: A Social Science Perspective (New York: Russell Sage Foundation, 1975) Irianto, Sulistyowati, Pluralisme Hukum di Indonesia dan Di Berbagai Negara Dalam Era Globalisasi (Jakarta: BPHN, 2007).

Irianto, Sulistyawati, "Menuju Pembangunan Hukum Pro-Keadilan Rakyat dan Perempuan" in Antonius Cahyadi and Dony Danardono (ed). Sosiologi Hukum dalam Perubahan (Jakarta : Yayasan Pustaka Obor Indonesia, 2009).

Kriekhoff,Valerine JL, "Mediasi : Tinjauan dari Segi Antropologi Hukum" dalam Ihromi, (ed). Antropologi Hukum Sebagai Bunga Rampai (Jakarta : Yayasan Obor Indonesia, 1993).

Kuntowijoyo, Radikalisasi Petani (Yogyakarta: Bentang Intervisi Utama, 1994).

\section{Journal}

Cindawati, 'Analisis Kekuatan Mengikat Kontrak Sebagai Dasar Yuridis Dalam Bisnis Internasional' (2016) 9(3) Arena Hukum.

Fatimah, Titik and Hengki Andora, 'Pola Penyelesaian Sengketa Tanah Ulayat Di Sumatera Barat' (2015) 4(1) Jurnal Ilmu Hukum.

Hasan, Ahmadi 'Penyelesaian Sengketa Melalui Upaya (Non Litigasi) Menurut Peraturan PerundangUndangan' (2007) 5 (January - June) Jurnal AL-BANJARI.

Hasanah, Uswatun and Et Al 'Penyelesaian Sengketa Tanah Waris Berbasis Kearifan Lokal Masyarakat Madura '(2017) Proceedings of UMM. Hasanah, Uswatun and Et Al., 'Pluralisme Hukum Dalam Penyelesaian Sengketa Warisan Pada Masyarakat Madura' (2018) 11(1) Arena Hukum.

Kaban, Maria 'Penyelesaian Sengketa Waris Tanah Adat Pada Masyarakat Adat Karo' (2016) 28(3) Mimbar Hukum.

Khairandy, Ridwan 'Landasan Filosofis Kekuatan Mengikatnya Kontrak' (2011) 18(October) Jurnal Hukum.

Muhlizi, Arfan Faiz 'Bantuan Hukum Melalui Mekanisme Nonlitigasi Sebagai Saluran Penguatan Peradilan Informal Bagi Masyarakat Adat' (2013) 2(1) Jurnal Rechtsvinding.

Ngutra, Theresia' Hukum dan Sumbersumber Hukum' (2016) 11(2) Jurnal Supremasi.

Puspitasari, Chandra Dewi 'Alternatif Penyelesaian Sengketa Asuransi Melalui Badan Mediasi Asuransi Indonesia (BMAI) (2007) 4(2), Journal Civics.

Rato, Dominikus 'Revitalisasi Peradilan Adat Pada Masyarakat Ngada Berbasis 
Kearifan Lokal' (2015) 92(May-

August) Yustisia.

Suharjono, Muhammad, 'Pembentukan

Peraturan Daerah yang Responsif

Dalam Mendukung Otonomi Daerah'

(2014) 10(Februay) Jurnal Ilmu

Hukum.

Sukresna, 'Pemberdayaan Lembaga Mediasi

Dalam Penyelesaian Sengketa Di

Bidang Pertanahan' (2012) 41(1)

MMH.

Sulistiyo, Iwan, Et Al, 'Implementasi Asas

Keterbukaan Dalam Proses

Pembentukan Peraturan Daerah dalam

Rangka Otonomi Daerah di Kabupaten

Kendal' (2018) 1(1) Jurnal Daulat

Hukum.

Wibowo, Gatot Dwi Endro, 'Aspek Hukum

dan Kelembagaan Dalam Peningkatan

Efisiensi dan Efektivitas Pengelolaan

Wilayah Pesisir' (2009) 16(1) Jurnal

Hukum.

Yulianti Rina and Sri

Maharani, 'Penyelesaian Sengketa
Informal Berbasis Komunitas Adat Terpencil di Kepulauan Kangean (Pilihan Hukum dan Posisi Dalam Sistem Hukum Negara)' (2012) 12(2) Jurnal Dinamika Hukum.

Acts

Undang-undang Nomor 30 Tahun 1999 tentang Arbitrase dan Alternatif Penyelesaian Sengketa.

Undang-undang Nomor 12 Tahun 2011 tentang Pembentukan Peraturan Perundang-undangan.

Undang-undang Nomor 6 Tahun 2014 tentang Desa.

Undang-undang Nomor 23 Tahun 2014 tentang Pemerintahan Daerah.

Keputusan Ketua Mahkamah Agung Republik Indonesia Nomor 117/KMA/SK/VI/2018 tentang Tata Cara Pemberian dan Perpanjangan Akreditasi Lembaga Penyelenggara Sertifikasi Mediator Bagi Mediator NonHakim. 